\title{
Analysis of Science Teacher Candidates' Relation between Scientific Creative Thinking Skills, Creative Problem Solving and Project Development Skills
}

\author{
Sibel Demir Kaçan ${ }^{1, *}$, and Fatma Şahin ${ }^{2}$ \\ ${ }^{1}$ Ondokuz Mayıs University Sciences, Education Faculty Science Education Department, Türkiye \\ ${ }^{2}$ Marmara University Sciences, Education Faculty Science Education Department, Türkiye
}

\begin{abstract}
The research aims to determine the "relationship between the scientific creative thinking skills and creative problem solving and project development skills of candidate science teachers." The research was performed with 24 teacher candidates in the control group and 24 teacher candidates in the experimental group in the second class of the Department of Science Teaching in a university in Istanbul Province. In the experimental group of the research, the laboratory program to be designed by the researchers on the basis of scientific discussion and research; and in the control group, the conventionally designed laboratory program were applied for 14 weeks. The research data was gained through "SelfAssessment for Creativity Questionnaire" to be developed by Raudsepp [28] and adapted by Sungur [30] into Turkish with the reliability value by Gülel [11]; two projects which were "the kite project", "bridge project from spaghetti macaroni" and "personal interviews". The conclusions to be reached by the research are in favour of the experimental group and the last application. While it was found that the project development processes of the candidate teachers in the experiment group had an important impact on their scientific creativity, the positive opinions of the candidate teachers were also found.
\end{abstract}

Keywords: Fen eğitimi, bilimsel yaratıcılık becerisi, yaratıcılık, öğretmen aday1 eğitimi, proje, STEM

\section{Introduction}

The creative thinking is seen as a quite equipped, high level thinking skill providing various thinking skills to bring together. The experts state that the students can be gained the thinking skills at all the stages of the education along with the intelligence and talents of them [25].

\footnotetext{
* Corresponding author: sibelfe@,hotmail.com; this article is part of the first author's doctoral thesis.
} 
In addition to that, the basic thinking form of creative thinking is generated by divergent and convergent thinking. The convergent thinking is the calm, careful, planned thinking by being clear and exact with positive judgements with reference to the aim [26]; the divergent thinking is the thinking permitting the imagination to be used for reaching more than one outcome without judging the thoughts for many alternatives as a result of a brainstorming in favour of new and different thoughts, pushing the individual borders more for producing ideas, providing time for idea formation, unification of the ideas [26]. The divergent thinking is generally seen as the way of thinking ensuring the creative thinking and problem solving with many right or wrong answers to be produced [13]. When the creative problem solving model to be developed by Lin and Cho [19] is examined, it is seen that the convergent thinking, divergent thinking, motivation and environment have relations with each other and this four situations form the general knowledge and skills in the life; however, only the divergent thinking can alone develop the creative problem solving, other three have firstly to enable the success and then bring a creative solution, if any. This is clearly indicate that the divergent thinking is quite a lot for a creative problem solving.

According to Meyer and Lederman [22], the creativity is the foundation of the scientific knowledge. The creativity is an enormous fact. Despite its basic consideration of many, various and original production, there are differences for the creativity in literature, art, social sciences and natural sciences. The human needs are firstly considered in scientific creativity and it is generally required to adapt current knowledge into new situations [Can, 2007; quoted by 15].

Park [27] states the scientific creativity with three dimensions which are creative thinking, scientific knowledge and scientific research and inquiry skills. On the other hand, Zhang, Liu and Lin [36] stated the existence of some requirements like internal motivation, autonomy and initiation, but these are also not sufficient. The problem solving, formation of hypothesis, test design, technical innovation require a certain form of creativity unique to the science [20].

The scientific creativity model of Hu and Adey [13] consists of three dimensions which are the process, characteristic (feature) and product. Thus, according to Demir [7], "The scientific creative thinking skill: It can be defined as a skill of thinking providing the formation of numerous original ideas in various fields for the solution of a problem for which the solution is required by the individual, with an innovative and interdisciplinary approach including the science, technology and art (aesthetics). With reference to this definition, the scientific creativity is considered as a multi-dimensional and equipped field ensuring either uniqueness to the field or the aesthetic approaches of various disciplines to bring together under the same roof."

If it is known how humans learn and how configure the knowledge, an appropriate learning environment can be formed [8]. This approach generates the essence of the learning and teaching experiences in the science education as the teaching on the basis of research and inquiry in the science education and special approach for the learning on the basis of research and inquiry in science teaching and learning [9]. The scientific research inquiry contains the way of thinking of scientists while they are searching the real world and the perception of how they work to develop the knowledge [24]. This approach is the process of problem solving with indoor and outdoor activities of the students [31] and there are numerous studies emphasizing its importance in various educational discipline in recent years [24].

On the point, the projects which can be used efficiently as a creative problem solving process are so important. The project is a model promoting research, developing creativity, containing indoor and outdoor activities focusing on the students with various disciplines and problem solving skills from the real life, the cognitive process, technology and team working [35]. In other words, the project enables to search the problem in depth; to decide 
independently, gaining scientific research skill [6] and existence of the creativity [2]. Since, the STEM activities which can also be performed as a project work can also be beneficial in that sense. STEM is an interdisciplinary look consisting of science, technology, engineering and mathematics. STEM enables individuals a way to reach the required resources by using the creativity in social life [29]. There are studies on STEM and its effects. For instance, in one of such studies, Wai, Lubinski, Benhow and Steiger [34] analyse the relationship between the success in science, technology, engineering, mathematics (STEM) and the real life; the study of Tyson, Lee, Borman and Hanson [33] analyse the relationship between the demographical characteristics of the students and STEM. As it is seen in these researches, the science, technology, engineering, mathematics education provides an interdisciplinary look to understand the life and this vision is seen as a perception promoting the flexibility and fluency criteria which are effective to reveal the creative potential of the individual. With reference to this point, the problem of the research to determine the "relationship between the scientific creative thinking skills and creative problem solving and project development skills of candidate science teachers."

\section{Methodology}

It is research model (pattern) that is the research plan to be developed deliberately by the researcher to control the variance in order to test the hypothesis or to answer the research questions [3; 4]. The mixed model is a dominant model that provides the qualitative and quantitative methods to distinguish, define and unite [23]. This mixed model is used for the research.

The universe of this research is the 1 st and 2 nd education programs students in the Department of Science Teaching in a university in Istanbul. The working group of the research consists of 2 nd grade of the Department of Science Teaching of the same university. The students selecting this course among candidate teachers in the 1 st education program formed the control group and the candidate teachers from the 2nd education program formed the experimental group. Thus, this research was conducted with 24 candidate teachers in the control group and 24 candidate teachers in the experimental group in the Department of Science Teaching.

The program to be developed by the researchers was designed with reference to the conventional laboratory program for the control group and $5 \mathrm{E}$ model on the basis of scientific discussion and research for the experimental group. This program was developed along with the pilot applications and it was developed and selected according to the opinions of candidate teachers within the framework of the pilot application and 2 expert researchers, from the pool containing various activities to be tried on working groups in order to ensure the validation and it was finalised.

The questionnaire "How creative are you?" to be developed by Raudsepp [28] was adapted by Sungur [30] into Turkish and after all the articles (50 articles) were reviewed by Gülel [11] in terms of Turkish language and literature with the linguists, the reliability value was determined as 0.761 Cronbach alpha. The Cronbach alpha value of this value for the research was found as 0,82 and the "Self-Assessment for Creativity Questionnaire" was applied to the candidate teachers in the control and experiment groups as the pre- and postapplication.

The research to be supervised for the process with the pilot application; in the research to be finalised with an exhibition, the spaghetti bridge project exhibition and kite project fest were performed by the candidate teachers in the experiment group. The similar studies of Gonzalez, Morsch and Masuero [10], and Karweit [14] were benefited for the spaghetti (macaroni) bridge project in the research. 
In the analysis of the qualitative data to be extracted from the research, the usual distribution was firstly considered and the Self-Assessment for Creativity Questionnaire was normal for all four groups. Therefore, the t-test analysis was performed for the measuring tool.

The analysis of the qualitative data to be gained from the research was made with the rubric to be formed by the researchers. The rubric criteria to be used for the teaching process and stages; "quite sufficient" means "all given answers are accepted as appropriate ideas"; "sufficient" means "despite some omission/mistake/contradiction... in given answers, appropriate ideas are more"; "insufficient" means "despite the appropriateness of ideas in given answers, more omission/mistake/contradiction"; " "quite insufficient" means "omission/mistake/contradiction in given answers completely" and "no answer" means "no answer was given.

\section{Findings}

Findings from this study are presented in tables (table 3.1., table 3.2., table3.3) below.

Table 3.1. The Findings on "Self-Assessment for Creativity Questionnaire" of Candidate Teachers

\begin{tabular}{lllll}
\hline & $\mathbf{N}$ & Ort. & $\mathbf{t}$ & $\mathbf{P}$ \\
\hline Control pre & 24 & 140,96 & 2,542 & 0,835 \\
\hline Experiment pre & 24 & 140,46 & & \\
\hline Control post & 24 & 152,33 & 2,542 & 0,014 \\
\hline Experiment post & 24 & 159,33 & & \\
\hline Control pre-post & 24 & $140,96-152,33$ & 4,059 & 0,000 \\
\hline Experiment pre-post & 24 & $140,46-159,33$ & 6,935 & 0,000 \\
\hline
\end{tabular}

As it is seen on the t-test results in Table 3.1, no meaningful difference was seen in pretest distributions of control and experiment groups. This means that both groups were at equal level for this questionnaire. In the post-test results of the control and experiment groups, there is a meaningful difference in favour of the experiment group. This situation indicate that there is a change in favour of the experiment group in this last test.

Table3.2. Findings on Kite Project

\begin{tabular}{|c|c|c|c|c|c|c|c|c|c|}
\hline & 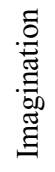 & 吽 & 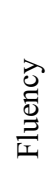 & 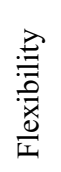 & 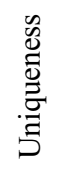 & 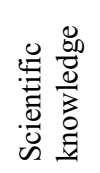 & 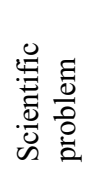 & 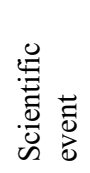 & 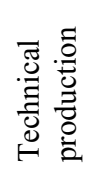 \\
\hline Group1 & 5 & 5 & 5 & 5 & 5 & 3 & 4 & 4 & 4 \\
\hline Group2 & 4 & 5 & 4 & 5 & 5 & 5 & 5 & 5 & 5 \\
\hline Group3 & 5 & 5 & 5 & 5 & 5 & 5 & 5 & 5 & 5 \\
\hline Group4 & 5 & 5 & 5 & 5 & 5 & 5 & 5 & 5 & 5 \\
\hline Group5 & 3 & 4 & 3 & 3 & 3 & 4 & 3 & 3 & 4 \\
\hline
\end{tabular}

As it is seen on Table 3.2, the groups developed successful projects in general. However, the kite to be made in a group was found insufficient in terms of its dimensions.

As it is seen on Table 3.3, the findings to be gained from the final projects of the groups for the spaghetti bridge exhibitions are found sufficient in general for their dimensions 
Table 3.3. Findings on Spaghetti Bridge Project

\begin{tabular}{|c|c|c|c|c|c|c|c|c|c|}
\hline & 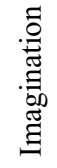 & 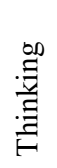 & 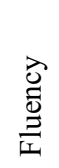 & 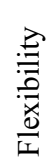 & 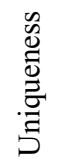 & 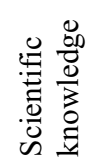 & 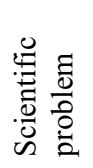 & 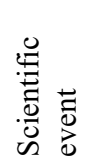 & 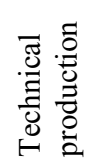 \\
\hline Group1 & 5 & 5 & 5 & 5 & 4 & 4 & 4 & 5 & 4 \\
\hline Group2 & 5 & 5 & 5 & 5 & 5 & 5 & 5 & 5 & 5 \\
\hline Group3 & 4 & 5 & 5 & 4 & 3 & 5 & 5 & 5 & 5 \\
\hline Group4 & 5 & 5 & 5 & 5 & 5 & 5 & 5 & 5 & 5 \\
\hline Group5 & 5 & 5 & 5 & 5 & 5 & 5 & 5 & 5 & 5 \\
\hline
\end{tabular}

\section{Discussion and Conclusion}

The conclusions to be reached by the research are in favour of the experimental group and the last application. While it was found that the project development processes of the candidate teachers in the experiment group had an important impact on their scientific creativity, the positive opinions of the candidate teachers were also found.

Despite low number of researches on scientific creativity, the number has been increasing in recent years. Liang [18] states that many researchers focus on the creative thinking, products and processes of the scientists in the researches on the scientific creativity, few researchers focus on the creativity of the students. The actions to be taken in the creative thinking may vary according to the structure of the problem to be worked on, it is considered as noticing and limiting the problem, forming hypothesis for the solutions, testing the hypothesis, finding the result, accepting or rejecting or changing [Sönmez, 1993, quoted by 1].

According to Chairman [5], in order to increase the quality of the education in the science and creativity program, the classes in which the teachers and the students involve in discussions; learning with doing and investigating; use of alternative teaching approaches including the use of computers, project works, simulation exercises and so on were mentioned. Especially in recent years, the students in the science education have been expected to have the skills starting from scientific process skills to research, questioning, problem solving, project development and indicating their creativity [32]. The neurobiological, psychological and cultural works generally indicate the creativity as a dialectical process between the configuration and non-configuration, the order and the chaos. The benefits of the interdisciplinary reflection in the creativity works in terms of the completion of special findings to be formed one by one in the fields of science are emphasized [12]. Therefore, the students in the research were especially promoted to express their opinions with reference to interdisciplinary thinking and this approach was tried to be applied in both the program contents and the projects.

The innovative perspective requires some uniqueness and interdisciplinary approach to the matters. The science is one of the best content fields to establish the interdisciplinary connections. Besides, the science courses give opportunities to reinforce the languages of the art and mathematics [16]. For the sake of the formation of the creative ideas, it is an important component to think with different dimensions through an interdisciplinary consideration. National research Centre (NRC) and AAAS strongly emphasize the provision of the science, technology, engineering and mathematics as a whole to the students [37]. 


\section{References}

1. Aktamış, H., \& Ergin, Ö. Fen eğitimi ve yaratıcılık. Dokuz Eylül Üniversitesi Buca Eğitim Fakültesi Dergisi, 20, 77-83, (2006).

2. Aykaç, N. Öğrenme-öğretme sürecinde öğretim stratejileri, yöntem ve teknikleri. N. Aykaç, \& H. A. (Eds.) içinde, Öğrenme-öğretme sürecinde planlama ve uygulama (s. 173-242). Ankara: Naturel Kitap Yayın Dağıtım, (2006).

3. Balc1, A. (2004). Sosyal bilimlerde araştırma yöntem, teknik ve ilkeler. Ankara: Pegem A Yayıncilık. 4. Bask1, (2004).

4. Büyüköztürk, Ş. Deneysel desenler öntest-sontest kontrol grubu desen ve veri analizi. Ankara: Pegem A Yayıncılık. 1.Baskı, (2001).

5. Chairman, B. P. (1994). www.teindia.nic.in/mhrd/50yrsedu/q/6J/BJ/6JBJ0101.htm adresinden 2 Aralık 2013 tarihinde edinilmiştir.

6. Çubukçu, A. Probleme dayalı öğrenme. B. Oral (Ed.) içinde, Öğrenme-öğretme kuram ve yaklaşımları (s. 527-540). Ankara: Pagem A Yayıncılık, (2012).

7. Demir, S. Bilimsel tartışma ve araştırmaya dayalı tasarlanan laboratuvar programının, fen bilgisi öğretmen adaylarının bilimsel yaratıcılıklarına etkisi. Yayınlanmamış Doktora Tezi, Marmara Üniversitesi, İstanbul, (2014).

8. Duban, N. İlköğretim fen ve teknoloji dersinin sorgulamaya dayalı öğrenme yaklaşımına göre işlenmesi: Bir eylem araştırması. Yayınlanmamış doktora tezi, Anadolu Üniversitesi, Eğitim Bilimleri Enstitüsü, Eskişehir, (2008).

9. Dunne, J., Mahdi, A., \& O'Reilly, J. Investigating the potential of irish primary school textbooks in supporting inquiry-based science education(1bse). International Journal of Science Education, 35(9), 1513-1532, (2013).

10. Gonzalez, L. A. S., Morsch, I. B., \& Masuero, J. R. Didactic games in engineering teaching-case: Spaghetti Bridges design and building contest. 18th International Congress of Mechanical Engineering. Ouro Preto, MG., (2005).

11. Gülel, G. Sınıf öğretmeni adaylarının yaratıcılık düzeylerinin çeşitli değişkenler açısından incelenmesi. Yayınlanmamış yüksek lisans tezi, Pamukkale Üniversitesi, Sosyal Bilimler Enstitüsü, (2006).

12. Holm-Hadulla, R. The dialectic of creativity: A synthesis of neurobiological, psychological, cultural and practical aspects of the creative process. Creativity Research Journal, 25(3), 293-299, (2013).

13. Hu, W., \& Adey, P. A scientific creativity test for secondary school students. International Journal of Science Education, 24(4), 389-403, (2002).

14. Karweit, M. What is engineering? Spaghetti bridge. (no date). http://web.archive.org/web/20080517124842/http://www.jhu.edu/virtlab/spaghettibridge/ adresinden 7 Ocak 2009 tarihinde edinilmiştir.

15. Kılıç, B. İlköğretim sekizinci sınıf öğrencilerinin bilimsel yaratıcılık ve bilimsel tutum düzeylerinin belirlenmesi. Yayınlanmamış yüksek lisans tezi, Eskişehir Osmangazi Üniversitesi, Eğitim Bilimleri Enstitüsü, Eskişehir, (2011).

16. Klentschy, M., \& Thompson, L. Scaffolding science inquiry through lesson design. Portsmouth, NH: Heinemann, (2008).

17. Levy, B. M., Thomas, E., Drago, K., \& Rex, L. Examining Studies of Inquiry-Based Learning in Three Fields of Education: Sparking Generative Conversation. Journal of Teacher Education, 64(5), 387-408, (2013). 
18. Liang, J. Exploring scientific creativity of eleventh grade students in Taiwan. Unpublished doctoral dissertation, The University of Texas at Austin, Texas, (2002).

19. Lin, C., \& Cho, S. Predicting creative problem-solving in math from a dynamic system model of creative problem solving ability. Creatıvity Research Journal, 23(3), 255261, (2011).

20. Lin, C., Hu, W., Adey, P., \& Shen, J. The influence of case on scientific creativity. Research in Science Education, 33, 143-162, (2003).

21. Lin, H., Hong, Z., Yang, K., \& Lee, S. The impact of collaborative reflections on teachers' inquiry teaching. International Journal of Science, 35(18), 3095-3116, (2013).

22. Meyer, A. A., \& Lederman, N. G. Inventing creativity: an exploration of the pedagogy of ingenuity in science classroom. School Science and Mathematics, 113(8), 400-409, (2013).

23. Moghaddam, F. M., Walker, B. R., \& Harre, R. Cultural distance, levels of abstraction and the advantages of mixed methods. A. Tashakkori, \& C. Teddlie (Eds.) içinde, Handbook of mixed methods in social \& behavioral research (s. 111-134). California: Sage Publication, (2003).

24. National Research Council (NRC). National science education standards. Washington, DC: National Academy Press., (2008).

25. Özden, Y. Öğrenme ve öğretme. Ankara: Pegem A Akademi. 11. Baskı, (2011).

26. Öznacar, M. D., \& Bildiren, A. Üstün zekalı öğrencilerin eğitimi ve eğitsel bilim etkinlikleri. Ankara: Anı Yayıncılık., (2012).

27. Park, J. Scientific creativity in science education. Journal of Baltic Science Education, 10(3), 144-145, (2011).

28. Raudsepp, E. How Creative Are You? (1979). http://everything2.com/title/How+Creative+Are+You adresinden 10 Kasim 2013 tarihinde edinilmiştir.

29. Roth, W., \& Van Eijck, M. Fullness of life as minimal unit: Science, technology, engineering, and mathematics (STEM) learning across the life span. Science Education, 94, 1027-1048, (2010).

30. Sungur, N. Yaratıcı düşünce. İstanbul: Evrim, (1997).

31. Şahan, H. H., Uyangör, N., \& Işıtan, S. Öğretim stratejileri. B. Oral içinde, Öğrenmeöğretme kuram ve yaklaşımları (s. 283-324). Ankara: Pegem A Yayıncılık, (2012).

32. Şahin, F., \& Benzer, E. The effect of the project practices improved with four question strategy to science process skills. Necatibey Eğitim Fakültesi Elektronik Fen ve Matematik Ĕgitimi Dergisi (EFMED), 6(1), 306-337, (2012).

33. Tyson, W., Lee, R., Borman, K., \& Hanson, M. A. Science, technology, engineering, and mathematics (stem) pathways: high school science and math coursework and postsecondary degree attainment. Journal of Education for Students Placed at Risk (JESPAR), 12(3), 243-270, (2007).

34. Wai, J., Lubinski, D., Benbow, C., \& Steiger, J. Accomplishment in science, technology, engineering, and mathematics (STEM) and its relation to Stem educational dose: A 25-year longitudinal study. Journal of Educational Psychology, 102(4), 860871, (2010).

35. Yavuz, S. Proje tabanlı öğrenme modelinin kimya eğitimi öğrencilerinin çevre bilgisi ile çevreye karşı tutumlarına olan etkisinin değerlendirilmesi. Yayınlanmamış doktora tezi, Hacettepe Üniversitesi, Fen Bilimleri Enstitüsü, Ankara, (2006). 
36. Zhang, J., Liu, G., \& Lin, C. An action-oriented approach to gifted education: Evidence from the field of scientific creativity. High Ability Studies, 23(1), 123-125, (2012).

37. Zubrowski, B. Integrating science into design technology projects: Using a standard model in the design process. Journal of Technology Education, 13(2), (2002). http://scholar.lib.vt.edu/ejournals/JTE/v13n2/zubrowski.html adresinden 11 Aralık 2013 tarihinde edinilmiştir. 